ISSN: $1410-8917$

Jurnal Kimia

Sains \&

Aplikasi
Jurnal Kimia Sains dan Aplikasi Journal of Scientific and Applied Chemistry

Journal homepage: http://ejournal.undip.ac.id/index.php/ksa

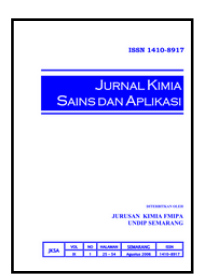

\title{
Studi Interaksi antara Segmen Dimer Kitin dengan Molekul Kalsium Fosfat Menggunakan Metode ab Initio
}

\author{
Ade Rahmani $^{\mathrm{a}}$, Tri Windarti ${ }^{\mathrm{a}}$, Parsaoran Siahaan ${ }^{\mathrm{a} *}$ \\ a Physical Chemistry Laboratory, Chemistry Department, Faculty of Sciences and Matematics, Diponegoro University, Jalan Prof. \\ Soedarto, Tembalang, Semarang \\ * Corresponding author: siahaan.parsaoran@live.undip.ac.id
}

\section{Article Info}

Keywords:

quantum

chemistry, chitin, calcium phosphate
Kata kunci:

kimia kuantum,

kitin, kalsium fosfat

\section{Abstract}

Chitin is a type of potential natural polysaccharide used as adsorbent. One example is the use of chitin as adsorbent in the manufacture of chitin-calcium phosphate composite. This research was a theoretical study with method of quantum chemistry ab initio at theory level and basis set $\mathrm{HF} / 6-31 \mathrm{G}(\mathrm{d}, \mathrm{p})$ to predict the structure and interaction happened in formation of chitin...calcium phosphate. The calculation result showed the interaction between dimer chitin and calcium phosphate. The interaction energy between dimer chitin with $\mathrm{Ca}^{+}$was $-359.837 \mathrm{~kJ} / \mathrm{mol}$ at a distance of $2.25 \AA$. The interaction between $\mathrm{PO}_{4}{ }^{3-}$ and a dimer chitin had energy of $-274.770 \mathrm{~kJ} / \mathrm{mol}$ at a distance of $3.20 \AA$. The interaction between $\mathrm{CaPO}_{4}^{-}$and a dimer chitin had energy of -64.058 $\mathrm{kJ} / \mathrm{mol}$ at a distance of $2.50 \AA$. For configuration of (dimer chitin...CaPO $\left.4_{4}^{-}\right) \mathrm{I}$ and for configuration of (dimer chitin...CaPO $4^{-}$) II was $-21.475 \mathrm{~kJ} / \mathrm{mol}$ at a distance $3.85 \AA$. The interaction energy between dimer chitin and $\mathrm{Ca}_{3}\left(\mathrm{PO}_{4}\right)_{2}$ was $-284.123 \mathrm{~kJ} / \mathrm{mol}$ at distance $2.55 \AA$. And the interaction between dimer chitin with $\left(\mathrm{Ca}_{5}\left(\mathrm{PO}_{4}\right)_{3} \mathrm{OH}\right)$ was -105.200 $\mathrm{kJ} / \mathrm{mol}$ at a distance $2.50 \AA$.

\section{Abstrak}

Chitin adalah polisakarida alami potensial yang digunakan sebagai adsorben. Salah satu contohnya adalah penggunaan kitin sebagai adsorben dalam pembuatan komposit kitinkalsium fosfat. Penelitian ini merupakan penelitian teoritis dengan metode kimia kuantum ab initio pada tingkat teori dan himpunan dasar HF/6-31G(d,p) untuk memprediksi struktur dan interaksi yang terjadi dalam pembentukan kitin-kalsium fosfat. Hasil perhitungan menunjukkan interaksi antara kitin dimer dan kalsium fosfat. Energi interaksi antara kitin dimer dengan $\mathrm{Ca}^{+}$adalah $-359,837 \mathrm{~kJ} / \mathrm{mol}$ pada jarak 2,25 $\AA$. Interaksi $\mathrm{PO}_{4}{ }^{3-}$ dengan kitin dimer memiliki energi -274,770 kJ/mol pada jarak 3,20 A. Interaksi $\mathrm{CaPO}_{4}{ }^{-}$dengan kitin dimer memiliki energi $-64,058 \mathrm{~kJ} / \mathrm{mol}$ pada jarak 2,50 A. Untuk konfigurasi (kitin dimer... $\mathrm{CaPO}_{4}^{-}$)II dan konfigurasi (kitin dimer... $\mathrm{CaPO}_{4}^{-}$)II sebesar $-21.475 \mathrm{~kJ} / \mathrm{mol}$ pada jarak 3,85 ̊. Energi interaksi antara kitin dimer dan $\mathrm{Ca}_{3}\left(\mathrm{PO}_{4}\right)_{2}$ adalah $-284.123 \mathrm{~kJ} / \mathrm{mol}$ pada jarak 2,55 $\AA$. Dan interaksi antara kitin dimer dengan $\left(\mathrm{Ca}_{5}\left(\mathrm{PO}_{4}\right)_{3} \mathrm{OH}\right)$ adalah $-105,200 \mathrm{~kJ} / \mathrm{mol}$ pada jarak 2,50 $\AA$.

\section{Pendahuluan}

Kitin, kitosan dan selulosa merupakan jenis polisakarida alam yang potensial dimanfaatkan sebagai adsorben [1]. Penelitian Madhumathi dkk. [2] menggunakan kitin sebagai adsorben untuk hidroksiapatit dalam pembuatan material komposit kitin-hidroksiapatit. Sedangakan Danilchenko dkk. [3] menggunakan kitosan sebagai adsorben pada pembuatan komposit kitosan-hidroksiapatit dan Hutchens dkk. [4] menggunakan hidrogel selulosa sebagai adsorben dalam pembuatan material komposit selulosa-hidroksiapatit. Penelitian-penelitian tersebut 
yang dilakukan adalah mengetahui kemampuan kitin, kitosan dan selulosa mengadsorbsi secara makroskopik tanpa menyampaikan informasi tentang kekuatan interaksi. Data mengenai kekuatan interaksi sangat diperlukan untuk mengetahui perbedaan kemampuan interaksi antara kitin, kitosan dan selulosa, karena adsorpsi sangat dipengaruhi oleh kekuatan interaksi antara adsorben dengan adsorbat. Kekuatan interaksi dapat ditentukan dengan eksperimen dan komputasi. Penentuan energi interaksi dalam penelitian ini dilakukan dengan metode komputasi.

Metode komputasi dapat digunakan untuk mengetahui proses yang terjadi dalam sintesis secara mikroskopis, diantaranya memprediksi struktur, distribusi muatan, frekuensi vibrasi dan juga interaksi antarmolekul secara akurat $[5,6]$. Penelitian Lü $d k k$. [7] menggunakan metode komputasi sebagai studi interaksi antara $\mathrm{Cu}^{2+}$ dengan kitin dan kitosan, sedangkan Ilchenko dan Leszczynski [8] menggunakan metode komputasi sebagai studi interaksi antara D-glukosamin dengan $\mathrm{Cd}^{2+}\left(\mathrm{H}_{2} \mathrm{O}\right)$. Siahaan [9] menggunakan metode komputasi untuk memprediksi kekuatan interaksi segmen molekul selulosa dengan kalsium fosfat. Besarnya energi interaksi antara segmen molekul selulosa dengan kalsium fosfat yaitu sebesar $-93,967$ $\mathrm{kJ} / \mathrm{mol}$ (dimer selulosa...Ca $\mathrm{Ca}_{5}\left(\mathrm{PO}_{4}\right)_{3} \mathrm{OH}$ ) dan $-65,355$ $\mathrm{kJ} / \mathrm{mol}$ (dimer selulosa...Ca $\left(\mathrm{PO}_{4}\right)_{2}$ menunjukan bahwa telah terjadi asosiasi segmen dimer selulosa dengan kalsium fosfat yang stabil.

Kitin dan kitosan mempunyai struktur dasar rantai yang sama dengan selulosa. Gugus fungsi yang terdapat pada kitin adalah $\mathrm{N}$-asetil, sedangkan pada kitosan terdapat gugus amina dan pada selulosa terdapat gugus $\mathrm{OH}$. Perbedaan gugus ini akan mempengaruhi besarnya energi interaksi terhadap kalsium fosfat. Sehingga pada penelitian ini dilakukan perhitungan interaksi antara dimer kitin dengan kalsium fosfat. Menurut penelitian Siahaan [9], konfigurasi interaksi ditentukan berdasarkan muatan parsial atom-atom penyusun interaksi antara dimer selulosa dan kalsium fosfat. Atom O ikatan $\beta(1,4) \mathrm{N}$-asetilglukosamina pada dimer kitin bermuatan parsial negatif dan atom Ca dari kalsium fosfat bermuatan positif. Sehingga dalam penelitian ini perhitungan energi interakasi ditentukan antara atom 0 ikatan $\beta(1,4)$ dengan atom Ca dari kalsium fosfat. Kalsium fosfat jenis $\mathrm{CaPO}_{4}{ }^{1-}$ mempunyai struktur yang tidak simetris. Hal ini menyebabkan kemungkinan interaksi (asosiasi) lebih dari satu konfigurasi. Oleh karena itu pada penelitian ini juga dilakukan perhitungan energi interaksi berbagai konfigurasi dari $\mathrm{CaPO}_{4}{ }^{1-}$ terhadap dimer kitin.

\section{Metode Penelitian}

Penelitian dilaksanakan di Laboratorium Kimia Fisik jurusan Kimia Fakultas Matematika dan Ilmu Pengetahuan Alam Universitas Diponegoro, Semarang. Alat yang digunakan adalah perangkat keras komputer klaster dengan sistem operasi Linux Mandriva 2009 dan perangkat komputer dengan sistem operasi Windows XP 2007. Sedangkan program komputasi yang digunakan adalah GAMESS dan untuk menampilkan struktur tiga dimensi digunakan program wxMacMolPlt, Molden, Chemcraft dan Avogadro. Perhitungan komputasi dilakukan menggunakan metode perhitungan mekanika kuantum $a b$ initio pada tingkat teori dan basis set HF/6$31 \mathrm{G}(\mathrm{d}, \mathrm{p})$.

\section{Tahap-Tahap Penelitian}

Perhitungan optimasi geometri ion/molekul.

Perhitungan optimasi geometri dimulai dengan penentuan struktur awal yang dinyatakan dalam matriks-Z sebagai data input. Kemudian dilakukan optimasi geometri molekul dengan program GAMESS untuk memperoleh energi molekul paling stabil. Optimasi geometri dilakukan terhadap ion/molekul tunggal, antara lain: ion $\mathrm{Ca}^{2+}$, ion $\mathrm{PO}_{4}^{3-}, \mathrm{CaPO}_{4}^{-}$, $\mathrm{Ca}_{3}\left(\mathrm{PO}_{4}\right)_{2}$, empiris hidroksiapatit $\left(\mathrm{Ca}_{5}\left(\mathrm{PO}_{4}\right)_{3} \mathrm{OH}\right)$, dan dimer kitin. Data perhitungan optimasi geometri ini memberikan informasi energi molekul, momen dipol dan distribusi muatan. Geometri optimasi ion/molekul tunggal selanjutnya digunakan untuk perhitungan asosiasi molekul berpasangan (interaksi antarmolekul).

\section{Perhitungan frekuensi dan penentuan spektra IR.}

Perhitungan frekuensi vibrasi dilakukan terhadap ion/molekul hasil optimasi geometri untuk mendapatkan data-data seperti frekuensi, dan intensitas relatif IR. Spektra IR molekul hasil perhitungan ditampilkan menggunakan program Avogadro.

Perhitungan $a b$ initio molekul berpasangan variasi jarak.

Perhitungan $a b$ initio molekul berpasangan dilakukan terhadap $\mathrm{Ca}^{2+}$...dimer kitin, $\mathrm{PO}_{4}{ }^{3-}$....dimer kitin, $\mathrm{CaPO}_{4}{ }^{-}$....dimer kitin, $\mathrm{Ca}_{3}\left(\mathrm{PO}_{4}\right)_{2}$....dimer kitin dan $\mathrm{Ca}_{5}\left(\mathrm{PO}_{4}\right)_{3} \mathrm{OH}$....dimer kitin dengan variasi jarak. Data perhitungan ini memberikan informasi energi sebagai fungsi jarak yang disimbolkan dengan $E_{A \ldots B}(R)$, dengan $A$ dan B adalah molekul atau ion yang berinteraksi. Sehingga untuk setiap interaksi molekul berpasangan masing-masing dapat dituliskan sebagai berikut:

$$
\begin{aligned}
& \Delta E_{\text {dimer kitin... } \mathrm{Ca}^{2+}}(\mathrm{R})=E_{\text {dimer kitin... } C a^{2+}}-\left(E_{\text {dimer kitin }}+E\right. \\
& \left.\mathrm{Ca}^{2+}\right) \\
& \Delta E_{\text {dimer kitin... } P O_{4}^{3-}}(\mathrm{R})=E_{\text {dimer kitin... } P O_{4}^{3-}}-\left(E_{\text {dimer kitin }}+E\right. \\
& \mathrm{PO}_{4}^{3-} \text { ) } \\
& \Delta E_{\text {dimer kitin... } \mathrm{CaPO}_{4}^{-}}(\mathrm{R})=E_{\text {dimer kitin... } \mathrm{CaPO}_{4}^{-}}-\left(E_{\text {dimer kitin }}+\right. \\
& \left.\mathrm{E} \mathrm{CaPO}_{4}^{-}\right)
\end{aligned}
$$

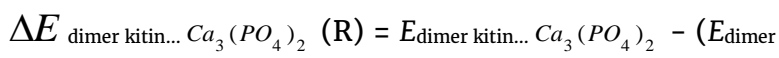

$$
\begin{aligned}
& \text { kitin } \left.+\mathrm{ECa}_{3}\left(\mathrm{PO}_{4}\right)_{2}\right)
\end{aligned}
$$

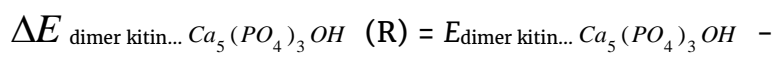

$$
\begin{aligned}
& \left(E_{\text {dimer kitin }}+\mathrm{ECa}_{5}\left(\mathrm{PO}_{4}\right)_{3} \mathrm{OH}\right)
\end{aligned}
$$


Pembuatan kurva potensial interaksi molekul berpasangan

Kurva energi potensial interaksi antarmolekul dibuat dengan hubungan antara $\Delta E_{A \ldots B}(R)$ dengan $R$. Data yang diperoleh antara lain, kedalaman potensial energi $\left(\varepsilon / \mathrm{kJmol}^{-1}\right)$ beserta jarak interaksinya. Data-data ini memberikan informasi kestabilan interaksi pada tiap molekul berpasangan.

\section{Hasil dan Pembahasan}

Geometri dan energi interaksi molekul dimer kitin...Ca ${ }^{2+}$.

Sehingga salah satu konfigurasi yang mungkin dari molekul berpasangan dimer kitin.... $\mathrm{Ca}^{2+}$ adalah pada posisi Ca terletak diatas permukaan dimer kitin disekitar atom oksigen pada ikatan $\beta(1,4)$ seperti pada gambar 1 .

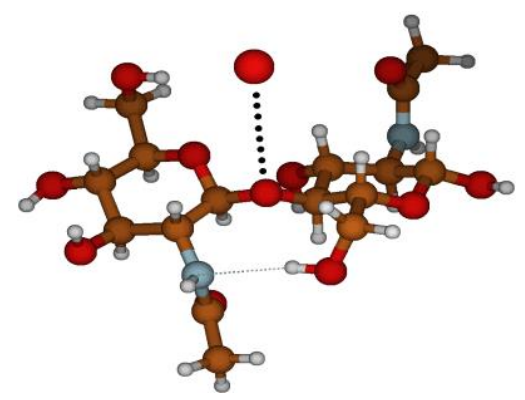

Gambar 1. Dimer kitin...Ca ${ }^{2+}$

Perhitungan energi interaksi asosiasi dimer kitin...... ${ }^{2+}$ dilakukan pada tingkat teori UHF/6-31G**. Energi interaksi dimer kitin...... ${ }^{2+}$ sebagai fungsi jarak ditampilkan dalam grafik $\Delta E(R)$ dengan $R$.

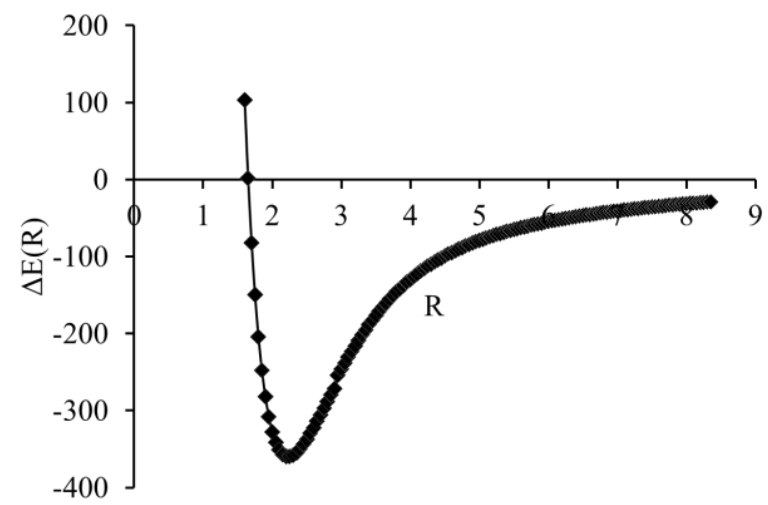

Gambar 2. Energi potensial interaksi dimer kitin...Ca ${ }^{2+}$

Grafik potensial interaksi menjelaskan adanya interaksi antara dimer kitin...... ${ }^{2+}$ dengan energi terendah sebesar $-359,837 \mathrm{~kJ} / \mathrm{mol}(-86,003 \mathrm{kkal} / \mathrm{mol})$ dengan jarak interaksi 2,25 $\AA$. Berdasarkan jarak interaksi dan energi interaksinya menunjukan interaksi dimer kitin...Ca ${ }^{2+}$ termasuk kategori interaksi van der Waals/ interaksi non kovalen. Energi interaksi hasil perhitungan interaksi dimer kitin...... ${ }^{2+}$ menunjukan lebih besar dari energi ikatan hidrogen kuat (14-40 $\mathrm{kkal} / \mathrm{mol}$ ) dan lebih kecil dari energi ikatan kovalen yaitu sekitar $100 \mathrm{kkal} / \mathrm{mol}$. Hal ini dikarenakan interaksi yang terjadi dipengaruhi oleh muatan/elektrostatik dari kation $\mathrm{Ca}^{2+}$. Sehingga interaksi yang terjadi antara dimer
kitin....Ca ${ }^{2+}$ dapat digolongkan dalam interaksi non kovalen.

Geometri dan energi interaksi molekul dimer kitin... $\mathrm{PO}_{4}^{3^{3-}}$.

Perhitungan energi potensial interaksi dimer kitin... $\mathrm{PO}_{4}{ }^{3-}$ sebagai fungsi jarak dilakukan pada tingkat teori dan basis set UHF/6-31G**. Kemudian hasil perhitungan ditampilkan dalam grafik hubungan antara $\Delta E(R)$ dengan $R$.

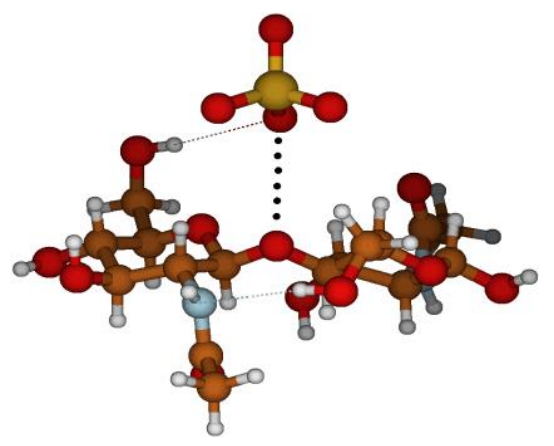

Gambar 3. dimer kitin...PO $4^{3-}$

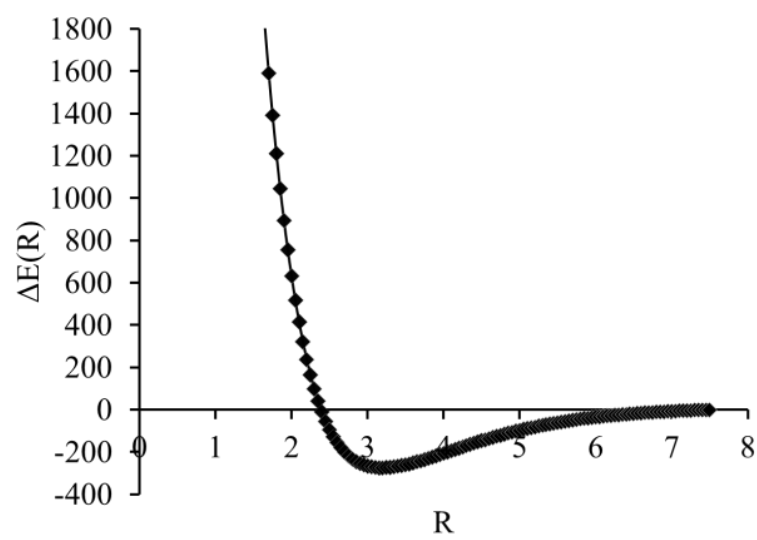

Gambar 4. Energi potensial interaksi dimer kitin...PO $\mathrm{PO}_{4}^{3-}$

Grafik potensial interaksi dimer kitin...PO ${ }_{4}^{3-}$ menunjukan energi interaksi terendah sebesar $-274,770$ $\mathrm{kJ} / \mathrm{mol}(-65,671 \mathrm{kkal} / \mathrm{mol})$, dengan jarak interaksi 3,2 $\AA$. Energi interaksi lebih besar dari energi ikatan hidrogen kuat (14-40 kkal/mol) dan lebih kecil dari energi ikatan kovalen yaitu sekitar $100 \mathrm{kkal} / \mathrm{mol}$ [10]. Meskipun jarak interaksi dimer kitin...fosfat berada dalam daerah jarak ikatan hidrigen lemah, akan tetapi energi interaksinya cukup besar, hal ini dikarenakan adanya pengaruh muatan dari anion $\mathrm{PO}_{4}{ }^{3-}$. Ditinjau dari jarak dan besar energi interaksinya, interaksi antara dimer kitin...Ca ${ }^{2+}$ dapat digolongkan dalam interaksi van der Waals/interaksi non kovalen. Pada konfigurasi interaksi dimer kitin...PO ${ }_{4}^{3-}$ juga menunjukan adanya ikatan hidrogen antara $\mathrm{O}-\mathrm{H}$ pada gugus hidroksimetil dimer kitin dengan salah satu atom oksigen dari ion $\mathrm{PO}_{4}{ }^{3-}$.

Geometri dan energi interaksi molekul dimer kitin... $\mathrm{CaPO}_{4}{ }^{1-}$.

Grafik potensial interaksi (dimer kitin...CaPO ${ }_{4}{ }^{1-}$ )I menunjukan energi interaksi terendah sebesar $-64,0578$ $\mathrm{kJ} / \mathrm{mol}(-15,310 \mathrm{kkal} / \mathrm{mol})$, dengan jarak interaksi 2,5. 
Berdasarkan jarak interaksi dan energi interaksinya menunjukan interaksi (dimer kitin....CaPO ${ }_{4}{ }^{1-}$ )I termasuk kategori ikatan hidrogen sedang (moderate).

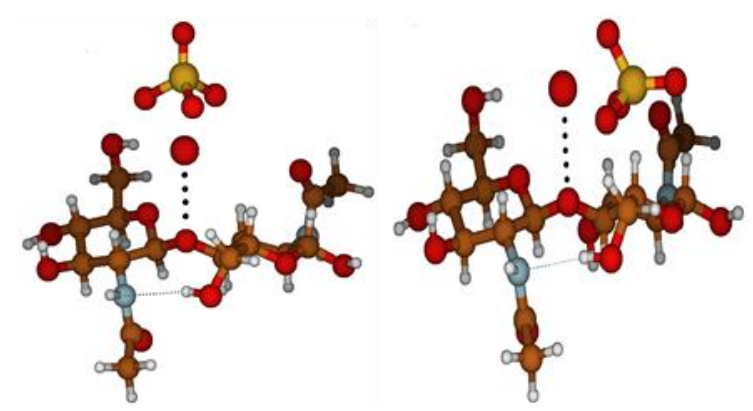

Gambar 5. Dimer kitin...CaPO ${ }_{4}^{1-}$

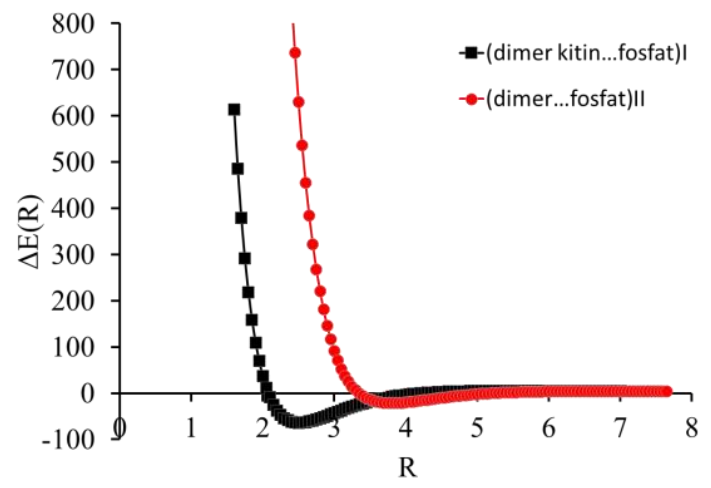

Gambar 6. Energi potensial interaksi dimer kitin...CaPO ${ }_{4}^{1-}$

Selanjutnya dilakukan perhitungan energi potensial interaksi (dimer kitin...CaPO ${ }_{4}{ }^{-}$)II sebagai fungsi jarak dilakukan pada tingkat teori dan basis set $\mathrm{UHF} / 6-31 \mathrm{G}^{* *}$. Grafik potensial interaksi (dimer kitin...(.CaPO ${ }_{4}{ }^{-1}$ )II menunjukan energi interaksi terendah sebesar $-21,475$ $\mathrm{kJ} / \mathrm{mol}(-5,132 \mathrm{kkal} / \mathrm{mol})$, dengan jarak interaksi 3,85 $\AA$. Dari grafik interaksi juga menunjukan pada jarak yang dekat (1,6 $\AA-3,30 \AA)$ terjadi tolak-menolak, interaksi tarik-menarik mulai terjadi pada jarak 3,35 $\AA$. Sehingga interaksi dimer kitin... $\mathrm{CaPO}_{4}{ }^{1-}$ pada konfigurasi (dimer kitin...CaPO $\left.{ }_{4}{ }^{1-}\right) \mathrm{II}$ lebih lemah jika dibandingkan dengan interaksi (dimer kitin...CaPO${ }_{4}{ }^{-}$)I.

Geometri dan energi interaksi molekul dimer kitin.... $\mathrm{Ca}_{3}\left(\mathrm{PO}_{4}\right)_{2}$.

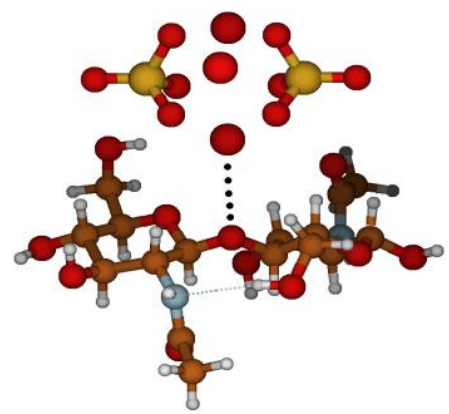

Gambar 7. Dimer kitin...Ca $\left(\mathrm{PO}_{4}\right)_{2}$

Grafik potensial interaksi dimer kitin...Ca $\left(\mathrm{PO}_{4}\right)_{2}$ menunjukkan energi interaksi terendah sebesar $284,123 \mathrm{~kJ} / \mathrm{mol}(-67,910 \mathrm{kkal} / \mathrm{mol})$ pada jarak interaksi
2,55 A. Sehingga dapat disimpulkan, dari hasil perhitungan $a b$ initio interaksi antara dimer kitin dengan trikalsium fosfat adalah stabil dan kuat. Ditinjau dari jarak ikatan dan energi potensial interaksi, interaksi antara dimer kitin dengan trikalsium fosfat adalah kuat, interaksi van der waals yang terjadi termasuk dalam kategori ikatan hidrogen kuat.

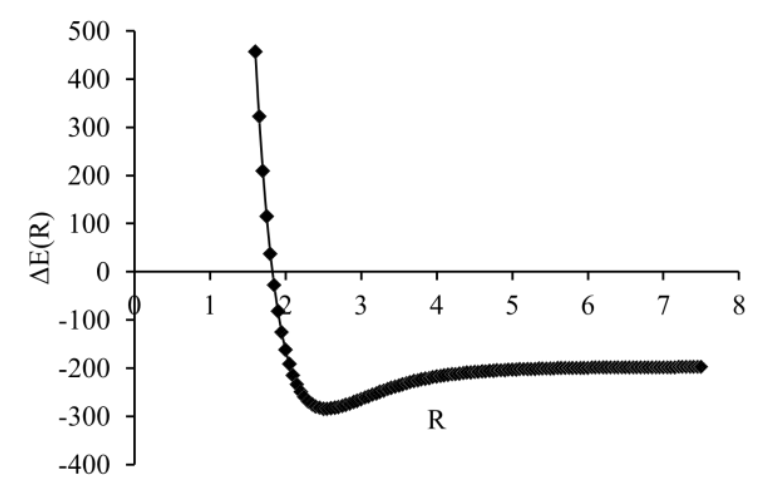

Gambar 8. Energi potensial interaksi dimer kitin.... $\mathrm{Ca}_{3}\left(\mathrm{PO}_{4}\right)_{2}$

Geometri dan energi interaksi molekul dimer kitin... $\left(\mathrm{Ca}_{5}\left(\mathrm{PO}_{4}\right)_{3} \mathrm{OH}\right)$.

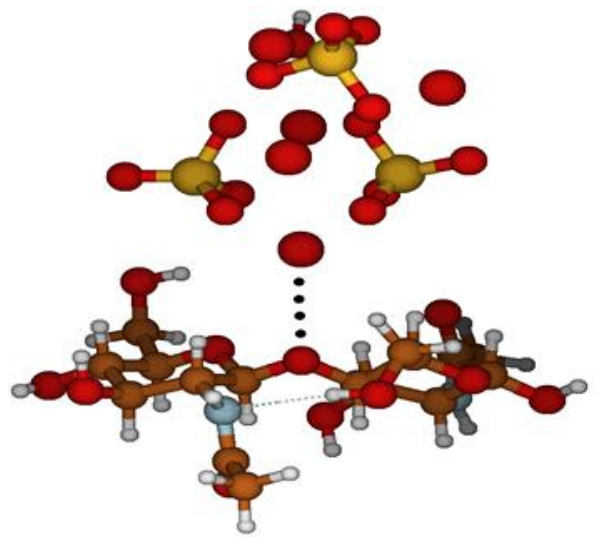

Gambar 9. Dimer kitin dengan $\mathrm{Ca}_{5}\left(\mathrm{PO}_{4}\right)_{3} \mathrm{OH}$

Hasil perhitungan menunjukan jarak paling stabil interaksi dimer kitin dengan $\mathrm{Ca}_{5}\left(\mathrm{PO}_{4}\right)_{3} \mathrm{OH}$ adalah pada jarak 2,5 $\AA$ dengan energi interaksi terendah sebesar 105,200 kJ/mol (-25,143 kkal/mol). Sehingga ditinjau dari jarak ikatan dan energi potensial interaksi, interaksi antara dimer kitin dengan $\mathrm{Ca}_{5}\left(\mathrm{PO}_{4}\right)_{3} \mathrm{OH}$ stabil, dengan interaksi van der Waals yang terjadi termasuk dalam kategori ikatan hidrogen kuat.

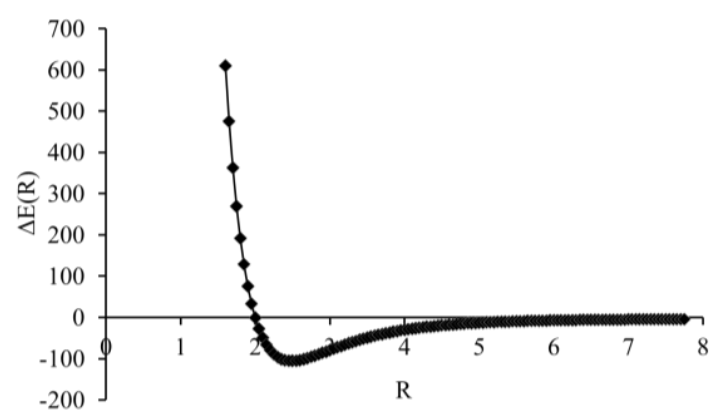

Gambar 10. Energi potensial interaksi dimer kitin dengan $\mathrm{Ca}_{5}\left(\mathrm{PO}_{4}\right)_{3} \mathrm{OH}$ 


\section{Kesimpulan}

Hasil perhitungan menunjukan bahwa telah terjadi interaksi antara dimer kitin dan kalsium fosfat. Energi interaksi antara dimer kitin dengan $\mathrm{Ca}^{+}$paling stabil sebesar $-359,837 \mathrm{~kJ} / \mathrm{mol}$ pada jarak 2,25 $\AA$. Interaksi $\mathrm{PO}_{4}{ }^{3-}$ dengan dimer kitin memiliki energi paling stabil

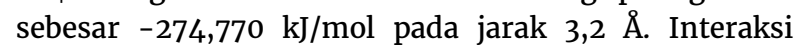
$\mathrm{CaPO}_{4}{ }^{1-}$ dengan dimer kitin memiliki energi paling stabil sebesar -64,058 kJ/mol pada jarak 2,5 $\AA$ untuk konfigurasi (dimer kitin...CaPO ${ }_{4}{ }^{1-}$ )I dan untuk konfigurasi (dimer kitin...CaPO $4^{1-}$ )II paling stabil sebesar -21,475 kJ/mol pada jarak 3,85 $\AA$. Energi interaksi antara dimer kitin dengan $\mathrm{Ca}_{3}\left(\mathrm{PO}_{4}\right)_{2}$ paling stabil sebesar -284,123 kJ/mol pada jarak 2,55 A. Dan energi interaksi antara dimer kitin dengan $\left(\mathrm{Ca}_{5}\left(\mathrm{PO}_{4}\right)_{3} \mathrm{OH}\right)$ paling stabil sebesar $-105,200 \mathrm{~kJ} / \mathrm{mol}$ pada jarak 2,5 $\AA$.

\section{Daftar Pustaka}

[1] Pradip Kumar Dutta, Joydeep Dutta, Vs Tripathi, Chitin and chitosan: Chemistry, properties and applications, (2004)

[2] K. Madhumathi, N. S. Binulal, H. Nagahama, H. Tamura, K. T. Shalumon, N. Selvamurugan, S. V. Nair, R. Jayakumar, Preparation and characterization of novel $\beta$-chitin-hydroxyapatite composite membranes for tissue engineering applications, International Journal of Biological Macromolecules, $\quad 44, \quad 1, \quad$ (2009) $\quad 1-5$ http://dx.doi.org/10.1016/j.ijbiomac.2008.09.013

[3] S. N. Danilchenko, Oksana Vladimirovna Kalinkevich, Maksim Vladimirovich Pogorelov, A. N. Kalinkevich, A. M. Sklyar, T. G. Kalinichenko, V. Y. Ilyashenko, V. V. Starikov, V. I. Bumeyster, V. Z. Sikora, Chitosan-hydroxyapatite composite biomaterials made by a one step co-precipitation method: preparation, characterization and in vivo tests, Journal of Biological Physics and Chemistry, 9, 3, (2009) 119-126

[4] Stacy A. Hutchens, Roberto S. Benson, Barbara R. Evans, Claudia J. Rawn, Hugh O'Neill, A resorbable calcium-deficient hydroxyapatite hydrogel composite for osseous regeneration, Cellulose, 16, 5, (2009) 887 https://doi.org/10.1007/s10570-0099300-6

[5] Athanassios Chrissanthopoulos, Evangelos Dalas, Semiempirical molecular orbital study of glycine solvation and of binding calcium carbonate on glycine polypeptides, Journal of Computational Methods in Sciences and Engineering, 7, 1, (2007) 7584

[6] A White, FJ Zerilli, HD Jones, Ab initio calculation of intermolecular potential parameters for gaseous decomposition products of energetic materials, in, 2000.

[7] Renqing Lü, Zuogang Cao, Guoping Shen, Comparative study on interaction between copper (II) and chitin/chitosan by density functional calculation, Journal of Molecular Structure: THEOCHEM, 860, 1, (2008) 80-85 http://dx.doi.org/10.1016/j.theochem.2008.03.013

[8] N. N. Ilchenko, J. Leszczynski, Ab initio study of interactions between d-glucosamine and
$\mathrm{Cd} 2+(\mathrm{H} 2 \mathrm{O}) \mathrm{n}, \mathrm{n}=0,2,4$, Journal of Molecular Structure: THEOCHEM, 683, 1, (2004) 23-27 http://dx.doi.org/10.1016/j.theochem.2004.06.028

[9] P. Siahaan, Windarti, T., and Muflikah, Infestigation of Molecular Interaction Between Can(fosfat)m and Segment of Cellulose-Dimer Glucose by Ab Initio QM Calculations, International Conference on Medical Chemistry, Bandung, (2009).

[10] Klaus Müller-Dethlefs, Pavel Hobza, Noncovalent interactions: a challenge for experiment and theory, Chemical Reviews, 100, 1, (2000) 143-168 http://dx.doi.org/10.1021/cr9900331 